\title{
Produksi Bibit Tempuyung (Sonchus arvensis L.) dengan Komposisi dan Volume Media Tumbuh yang Berbeda
}

\author{
Production of Perennial Sow Thistle Seedling (Sonchus arvensis L.) Using Different \\ Composition and Volume of Growth Media
}

\author{
Ahmad Nur Hidayat Gena Ari ${ }^{1 *}$, Maya Melati ${ }^{2}$, dan Sandra A. Aziz ${ }^{2}$
}

Diterima 20 Juni 2016/Disetujui 26 Oktober 2016

\begin{abstract}
Perennial sow thistle (Sonchus arvensis L.) is one of medicinal plants which has potential in healing kidney disease. However, quality and sufficient supply of perennial sow thistle seedling with good quality is inadequate. This research was aimed at producing perennial sow thistle seedling generatively and to determine the suitable type of growth media and media volume for its production. The experiment was conducted in experimental field at Cikarawang, IPB from October 2015 to January 2016. The experiment was laid out in completely factorial randomized design (3x3) with three replications. The two of treatment factors were volume of growth media $(9,12$, and 29 $m L)$ and composition of growth media (100\% goat manure, 50\% goat manure $+50 \%$ rice hull charcoal, and $33 \%$ goat manure $+33 \%$ rice hull charcoal $+33 \%$ coco peat $)(v: v)$. The results showed that larger media volume produced better perennial sow thistle seedling. There was significant effect of interaction between media volume and composition of growth media to some variables: leaf number, leaf length, leaf width, plant weight, shoot weight, root length, and total flavonoid concentration. The result showed that 50\% goat manure $+50 \%$ rice hull charcoal and combination of media volume $12 \mathrm{~mL}$ was strongly recommended for production of perennial sow thistle seedling.
\end{abstract}

Keywords: coco peat, flavanoid, manure, rice hull, seedling

\begin{abstract}
ABSTRAK
Tempuyung (Sonchus arvensis L.) merupakan salah satu tanaman obat yang berpotensi untuk mengatasi masalah penyakit batu ginjal. Besarnya potensi yang dimiliki oleh tempuyung belum diimbangi dengan penyediaan bibit yang baik dan jumlah yang besar. Penelitian ini bertujuan untuk memproduksi bibit tempuyung melalui pembibitan secara generatif, serta menentukan jenis media tanam dan volume media yang tepat. Percobaan dilakukan di kebun percobaan Cikarawang IPB, pada bulan Oktober 2015 sampai Januari 2016. Percobaan menggunakan Rancangan Acak Lengkap (RAL) dengan 2 faktor, faktor pertama adalah jenis komposisi media tanam yaitu menggunakan $100 \%$ pupuk kandang kambing, 50\% pupuk kandang kambing+ 50\% arang sekam, dan 33\% pupuk kandang kambing $+33 \%$ arang sekam $+33 \%$ cocopeat (v:v), faktor ke dua adalah volume media dengan ukuran 7.9, 12, dan $29 \mathrm{~mL}$ tiap lubang pada tray, setiap perlakuan memiliki 3 ulangan. Hasil penelitian menunjukkan bahwa perlakuan volume media yang lebih besar $(29 \mathrm{~mL})$ menghasilkan pertumbuhan dan hasil bibit tempuyung yang lebih baik. Terdapat pengaruh interaksi antara perlakuan jenis komposisi media dan volume media terhadap peubah jumlah daun, panjang daun, lebar daun, bobot total dan bobot tajuk tanaman, panjang akar serta kadar total flavonoid. Perlakuan media terbaik untuk produksi bibit tempuyung komposisi media 50\% pupuk kandang kambing + $50 \%$ arang sekam (v:v) dengan volume media $12 \mathrm{~mL}$.
\end{abstract}

Kata kunci : arang sekam, cocopeat, flavonoid, pembibitan, pupuk kandang kambing

${ }^{1}$ Program Studi Agronomi dan Hortikultura, Sekolah Pascasarjana, Institut Pertanian Bogor

J1. Meranti Kampus IPB Darmaga, Bogor 16680, Indonesia

${ }^{2}$ Departemen Agronomi dan Hortikultura, Fakultas Pertanian, Institut Pertanian Bogor

J1. Meranti Kampus IPB Darmaga, Bogor 16680, Indonesia

Email: ahmadnur.h.g.a.09@gmail.com (*penulis korespondensi) 


\section{PENDAHULUAN}

Tempuyung telah ditetapkan oleh Badan Pengawas Obat dan Makanan (BPOM) sebagai salah satu dari 13 spesies unggul bahan obat asli Indonesia (Deptan, 2002). Menurut Hidayati et al. (2009) tempuyung memiliki khasiat untuk mengatasi masalah penyakit batu ginjal. Daun tempuyung mengandung senyawa bioaktif dan salah satunya adalah flavonoid yang memiliki turunan di antaranya adalah apigenin 7-glukosida dan luteolin 7-glukosida (Pramono et al., 1993). Menurut Syukur dan Hernani (2002) selain mengatasi penyakit batu ginjal daun tempuyung juga berfungsi untuk mengatasi tekanan darah tinggi, obat bengkak, menghilangkan rasa lesu dan pegal, dan beberapa penyakit lainnya.

Besarnya potensi yang dimiliki tempuyung masih belum diimbangi oleh penyediaan bahan baku untuk menghasilkan simplisia. Hal ini, disebabkan belum adanya SOP yang tepat untuk menghasilkan simplisia yang diharapkan. Penentuan teknik budidaya mulai dari pembibitan hingga pascapanen yang meliputi aspek-aspek budidaya yang baku perlu dipelajari.

Saat ini, penyediaan bibit tempuyung masih belum bisa memenuhi untuk kebutuhan penanaman dalam jumlah besar, karena umumnya perbanyakan tanaman menggunakan anakan yang diperoleh dari tanaman liar. Penyediaan bahan tanam dalam jumlah besar bisa menggunakan bibit asal benih, namun terkendala belum adanya standar yang tepat untuk pembibitan. Pemilihan bibit, jenis media dan volume media untuk pembesaran merupakan informasi yang masih dibutuhkan. Selain itu trend produk tanaman obat saat ini lebih ditekankan ke arah organik dengan alasan lebih aman untuk kesehatan dibandingkan dengan produk yang menggunakan bahan kimia. Menurut Heni (2012) produk organik memiliki beberapa keuntungan diantaranya adalah kesehatan konsumen, pupuk organik mengembalikan kesuburan tanah dan kelestarian lingkungan, serta meningkatkan pendapatan petani karena harga jualnya lebih tinggi dari produk konvensional, Mayrowani et al. (2010) menambahkan pendapatan petani organik meningkat $20-30 \%$ dibandingkan dengan cara konvensional. Untuk itu, mulai dari pembibitan sampai dengan pascapanen diharapkan tidak menggunakan bahan kimia atau inorganik, sehingga pembibitan yang diharapkan adalah berbasis organik. Untuk itu penggunaan media tanam organik, seperti pupuk kandang, arang sekam, cocopeat dan bahan organik lain yang bisa dimanfaatkan sebagai media tanam.

Jenis media dan volume media tanam merupakan faktor penting yang harus diperhatikan, hal ini berkaitan erat dengan pertumbuhan tanaman. Penggunaan media yang memiliki porositas tinggi mendukung pertumbuhan akar namun media beresiko akan lebih cepat mengalami kekurangan air. Sebaliknya apabila menggunakan media dengan porositas yang rendah dapat menghambat pertumbuhan akar meskipun daya pegang air mungkin lebih baik daripada yang media ringan. Pemilihan volume media yang menjadi tempat ruang gerak akar juga dapat mempengaruhi pertumbuhan tanaman. Semakin besar volume media semakin baik pertumbuhan bibit tanaman, tetapi menghasilkan jumlah bibit akan lebih sedikit dengan luasan area pembibitan yang sama. Penelitian ini bertujuan untuk menentukan jenis media tanam dan volume media yang tepat untuk produksi bibit tempuyung. Pentingnya peranan jenis media dan volume media perlu dipelajari lebih agar bisa dijadikan rekomendasi untuk produksi bibit tempuyung menguntungkan dari segi budidaya dan segi ekonomi.

\section{BAHAN DAN METODE}

Percobaan dilaksanakan di kebun percobaan Cikarawang IPB kabupaten Bogor dengan menggunakan screen house, pengukuran kandungan flavonoid dilakukan di Pusat Studi Biofarmaka, Taman Kencana Bogor. Percobaan dilaksanakan dari bulan Oktober 2015 sampai bulan Januari 2016. Bahan tanam yang digunakan adalah benih tempuyung liar, pupuk kandang kambing, arang sekam, media, plastik bening, dan cocopeat. Alat yang digunakan di antaranya adalah timbangan digital, mikropipet, spektrofotometer, dan sentrifuge, serta alat pendukung lainnya.

Percobaan menggunakan Rancangan Acak Lengkap (RAL) dengan 2 faktor. Faktor pertama adalah jenis media tanam yang terdiri atas (1) $100 \%$ pupuk kandang kambing, (2) 
$50 \%$ pupuk kandang kambing $+50 \%$ arang sekam dan (3) 33\% pupuk kandang kambing+ $33 \%$ arang sekam $+33 \%$ cocopeat (v:v). Faktor ke dua adalah volume media yang terdiri atas (1) Volume $7.9 \mathrm{~mL}$ yaitu dengan 200 lubang masing-masing dengan diameter $2.5 \mathrm{~cm}$ tinggi $3 \mathrm{~cm}$, (2) Volume $12 \mathrm{~mL}$ yaitu dengan 105 masing-masing dengan diameter $3.5 \mathrm{~cm}$ dan tinggi $4.5 \mathrm{~cm}$, dan (3) Volume 29 $\mathrm{mL}$ yaitu dengan masing-masing dengan diameter $4.5 \mathrm{~cm}$ dan tinggi $4.5 \mathrm{~cm}$. Setiap perlakuan diulang sebanyak 3 kali.

Sebelum dilakukan penanaman di masing-masing perlakuan, benih disemai terlebih dahulu. Media semai yang digunakan terdiri atas beberapa komposisi yang terdiri atas arang sekam, pupuk kandang kambing dan cocopeat, masing-masing komposisi media dicampur hingga merata dengan perbandingan $1: 1: 1 \quad$ (v:v). Persemaian dilakukan pada bak perkecambahan, dilakukan dengan menebar biji tempuyung secara merata kemudian ditutup kembali dengan media campuran tersebut secara merata dan dilakukan penyiraman. Setelah umur 1 minggu setelah semai, kecambah tempuyung dipindahkan pada media sesuai perlakuan.

Pengamatan pertumbuhan dilakukan pada bibit tempuyung pada umur 3 minggu setelah semai (MSS). Pengamatan dilakukan pada tiga tanaman contoh pada setiap perlakuan, meliputi panjang daun, lebar daun, dan jumlah daun, diamati pada minggu ke 3, 5 , dan minggu ke 7 MSS. Bobot total bibit, bobot tajuk bibit, bobot akar bibit, panjang akar, volume akar, serta kadar flavonoid, diukur pada saat akhir pengamatan. Penentuan kandungan flavonoid bibit menggunakan metode yang dikemukakan oleh Lamaison dan Carnet (1990). Tahapan analisis kadar total flavonoid adalah dengan melarutkan sampel sebanyak $5 \mu \mathrm{L}$ ke dalam $95 \mu \mathrm{L}$ methanol, 400 $\mu \mathrm{L}$ aquadest kemudian ditambahkan $30 \mu \mathrm{L} 5 \%$ $\mathrm{NaNO}_{2}$ setelah itu diinkubasi selama 5 menit. Campuran tersebut ditambah dengan $30 \mu \mathrm{L}$ $10 \% \mathrm{AlCl}_{3}$ lalu diikubasikan selama 6 menit. Selanjutnya menambahkan $200 \mu \mathrm{L} 1 \mathrm{~N} \mathrm{NaOH}$ dan $280 \mu \mathrm{L}$ aquadest ke dalam larutan tersebut. Nilai absorbansi diukur pada panjang gelombang $415 \mathrm{~nm}$. Quercetin digunakan sebagai standar. Ekstraksi dilakukan menggunakan metode yang dikemukakan oleh Makkar et al. (1988) yang telah dimodifikasi.

Data pengamatan yang diperoleh, dianalisis menggunakan uji $\mathrm{F}$ pada $\alpha=5 \%$. Pada pengaruh perlakuan yang nyata terhadap peubah yang diamati, dilakukan uji lanjut DMRT (Duncan's Multiple Range Test) pada taraf kesalahan 5\%.

\section{HASIL DAN PEMBAHASAN}

Jenis dan volume media berpengaruh terhadap pertumbuhan bibit. Respon bibit menunjukkan bahwa peranan volume ruang gerak akar pada pembibitan tanaman tempuyung yang dilakukan pada berbagai macam ukuran volume media yang dikombinasikan dengan komposisi media yang berbeda, akan menghasilkan pertumbuhan tanaman yang berbeda-beda pula. Keragaan bibit antara jenis dan volume media disajikan pada Gambar 1. yang merupakan hasil dari perlakuan volume media dan media yang diberikan.

\section{Pengaruh Jenis dan Volume Media terhadap Peubah Pertumbuhan Bibit Tempuyung}

Hasil yang diperoleh menunjukkan bahwa media dengan volume $29 \mathrm{~mL}$ merupakan wadah yang paling baik untuk semua peubah (Tabel 1). Volume media yang besar, menyediakan ruang tumbuh akar maupun tajuk bibit akan semakin luas karena ruang jarak antar lubang lebih lebar, sehingga pertumbuhan bibit menjadi lebih baik dibandingkan dengan ruang gerak yang sempit. Penelitian Surata (2012) juga menunjukkan bahwa penambahan volume ukuran kantung plastik yang semakin besar menghasilkan pertumbuhan dan kualitas bibit tanaman cendana yang lebih baik. Pengaruh interaksi antara jenis dan volume media berbeda nyata terhadap jumlah, panjang dan lebar daun, meskipun tidak pada setiap waktu pengamatan. Daun akan semakin panjang dengan penambahan volume media namun jika menggunakan jenis media pupuk kandang kambing, maka ukuran daun akan lebih panjang, pola yang relatif sama terjadi pada lebar daun pada 7 MSS. 


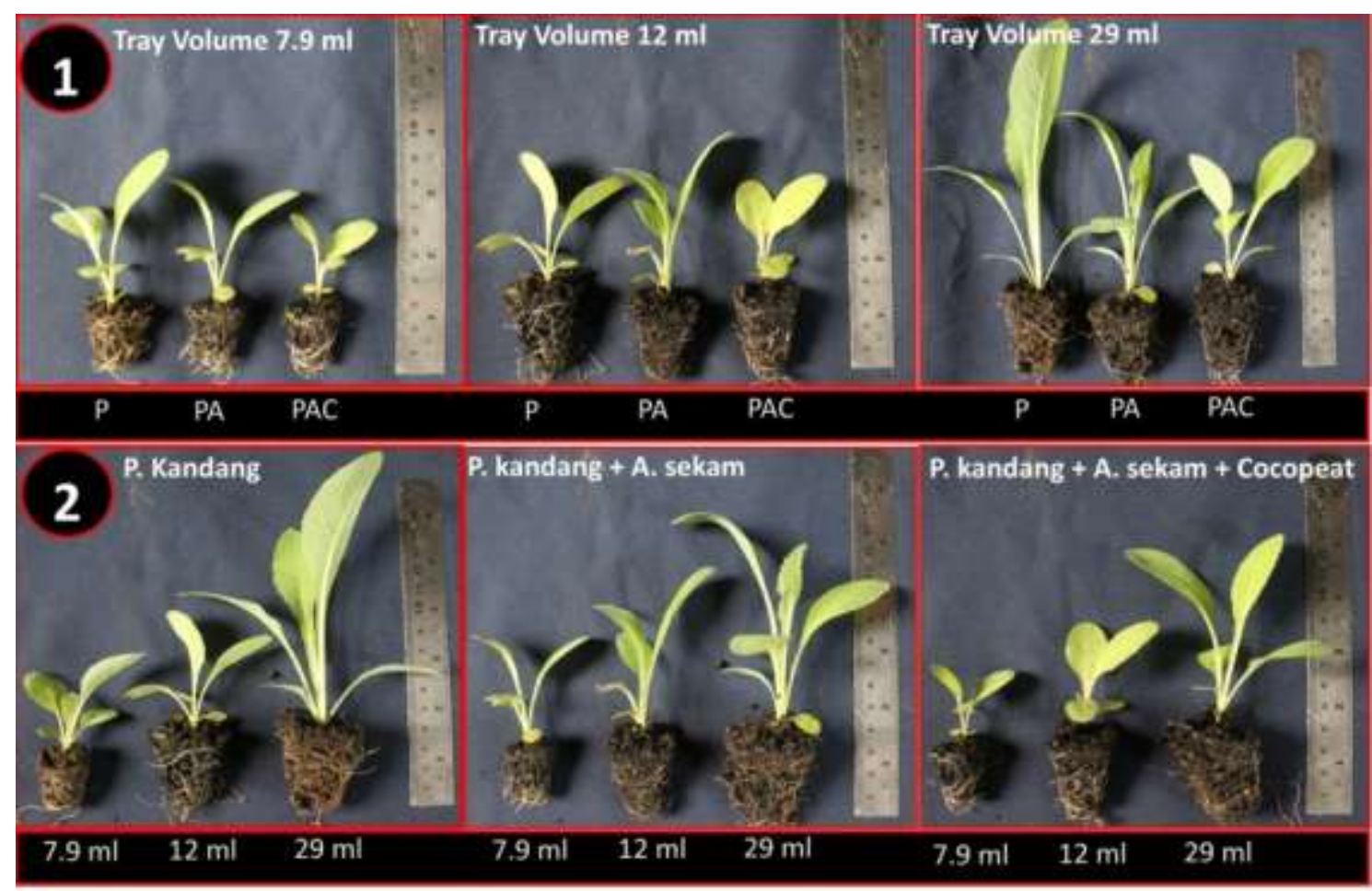

Gambar 1. Keragaan bibit tempuyung pada setiap perlakuan jenis dan volume media yang berbeda umur 7 MSS (Keterangan: (1) bibit pada jenis media yang berbeda, (2) bibit pada volume media yang berbeda, $\mathrm{P}=100 \%$ pupuk kandang kambing, $\mathrm{PA}=50 \%$ pupuk kandang kambing $+50 \%$ arang sekam dan $\mathrm{PAC}=33 \%$ pupuk kandang kambing $+33 \%$ arang sekam $+33 \%$ cocopeat)

Peubah jumlah daun pada 3 MSS tidak mengalami perbedaan yang nyata, begitu juga pada peubah diameter tajuk. Perlakuan yang diberikan mulai berpengaruh terhadap pertumbuhan pada $5 \mathrm{MSS}$, hal ini disebabkan karena bibit pada saat awal penanaman masih dapat mencukupi kebutuhan hidup, sedangkan di minggu-minggu berikutnya bibit sudah mulai membutuhkan hara, luasan pergerakan akar untuk menunjang pertumbuhan.

Saat tanaman berumur 7 MSS, diketahui bahwa kombinasi perlakuan yang paling baik adalah perlakuan dengan menggunakan komposisi median $100 \%$ pupuk kandang kambing dengan volume media $29 \mathrm{~mL}$ dibandingkan dengan perlakuan lainnya (Tabel 1). Pupuk kandang kambing juga digunakan pada penelitian Wardani dan Melati (2014) dengan dosis yang berbeda namun tidak memberikan pengaruh yang nyata terhadap peubah pertumbuhan tanaman tempuyung di lapangan.

Media yang baik adalah media yang mempunyai empat fungsi utama yaitu memberi unsur hara dan sebagai media perakaran, menyediakan air dan tempat penampungan air, menyediakan udara untuk respirasi akar dan sebagai tempat tumbuhnya tanaman (Haryati dan Kosasi, 2006). Hampir di semua peubah pertumbuhan memiliki pola pertumbuhan yang sama, yaitu pada perlakuan media yang menggunakan pupuk kandang kambing $100 \%$ (P) pada minggu-minggu awal memiliki pola pertumbuhan yang paling rendah dibandingkan dengan perlakuan media lainnya, tetapi pada pengamatan $5 \mathrm{MSS}$ menunjukkan peningkatan yang cukup signifikan dibanding perlakuan lain. Perlakuan media dengan komposisi $33 \%$ pupuk kandang kambing $+33 \%$ arang sekam $+33 \%$ cocopeat (PAC) yang pada minggu-minggu awal memiliki pertumbuhan yang paling baik, tetapi pada minggu berikutnya (5 MSS) mengalami penurunan. Hal ini disebabkan karena adanya penambahan cocopeat pada komposisi media yang diberikan. 
Tabel 1. Pengaruh interaksi perlakuan jenis dan volume media tanam terhadap peubah pertumbuhan bibit tempuyung pada umur 3, 5, dan 7 MSS

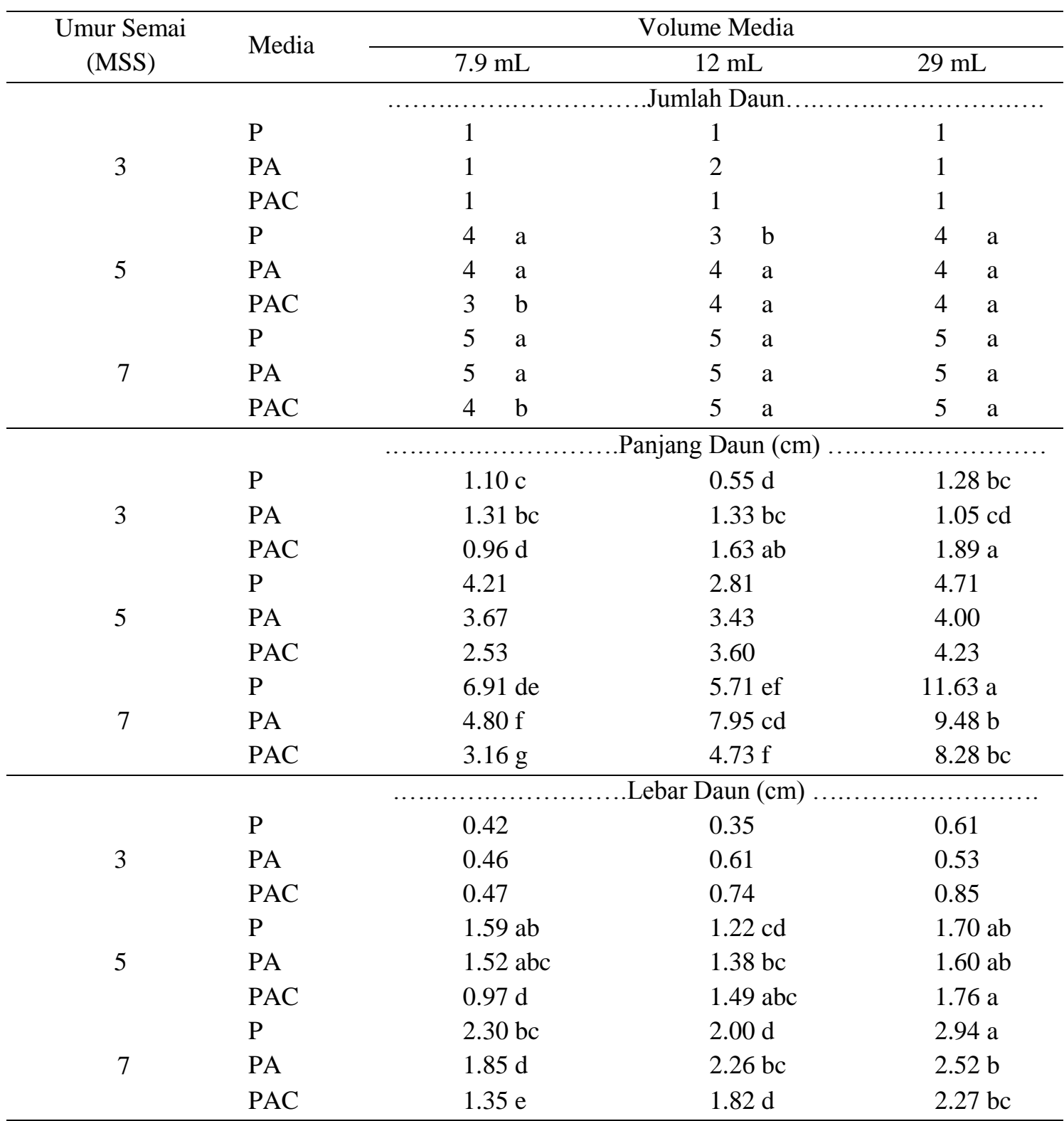

Keterangan: Angka pada tiap kolom dan baris yang diikuti huruf yang sama pada minggu yang sama tidak berbeda nyata berdasarkan uji DMRT 5\% ( $\mathrm{P}=100 \%$ pupuk kandang kambing, $\mathrm{PA}=50 \%$ pupuk kandang kambing $+50 \%$ Arang sekam, PAC $=33 \%$ Pupuk kandang kambing $+33 \%$ arang sekam $+33 \%$ Cocopeat).

Hasil penelitian Irawan dan Kafiar (2015) menunjukkan bahwa penambahan cocopeat pada media tanam akan memberikan hasil yang lebih rendah dibandingkan dengan media yang tidak diberi cocopeat. Hal tersebut disebabkan oleh pertukaran gas pada media mengalami hambatan karena media mulai jenuh oleh air, sehingga akar mengalami hambatan, udara dalam media akan semakin berkurang sehingga dapat menghambat pertumbuhan tanaman. Selain itu, faktor lain yang mungkin dapat mempengaruhi pertumbuhan bibit tempuyung adalah tingginya $\mathrm{C} / \mathrm{N}$ rasio yang terdapat pada cocopeat yang mencapai $48.47 \%$ (Ghehsareh et al., 2011), sehingga kandungan nitrogen yang ada pada media campuran cocopeat akan lebih kecil karena terserap untuk proses dekomposisi, sehingga pertumbuhan bibit akan terhambat. 
Pengaruh Jenis dan Volume Media terhadap Peubah Bobot Total Bibit, Bobot Tajuk, Bobot Akar, Volume Akar dan Panjang Akar Bibit Tempuyung

Terdapat pengaruh interaksi nyata antara perlakuan jenis dan volume media tanam terhadap peubah bobot total bibit, bobot tajuk bibit dan panjang akar, sedangkan pada peubah bobot dan volume akar tidak terjadi interaksi. Gambar 2 menunjukkan bahwa perlakuan terbaik terhadap bobot total dan bobot tajuk bibit adalah perlakuan menggunakan volume media $29 \mathrm{~mL}$ dengan media tanam 33\% pupuk kandang kambing + $33 \%$ arang sekam $+33 \%$ cocopeat (PAC) yaitu sebesar $1.16 \mathrm{~g} \mathrm{BB} /$ bibit.

Tidak terdapat pengaruh interaksi perlakuan terhadap peubah bobot akar dan volume akar (Tabel 2), namun terdapat pengaruh tunggal volume media. Semakin besar volume media yang digunakan maka akan semakin baik pertumbuhan akar bibit tempuyung. Perbedaan komposisi media tidak mempengaruhi bobot dan volume akar meskipun nilai keduanya lebih rendah jika dibandingkan dengan yang tanpa cocopeat.
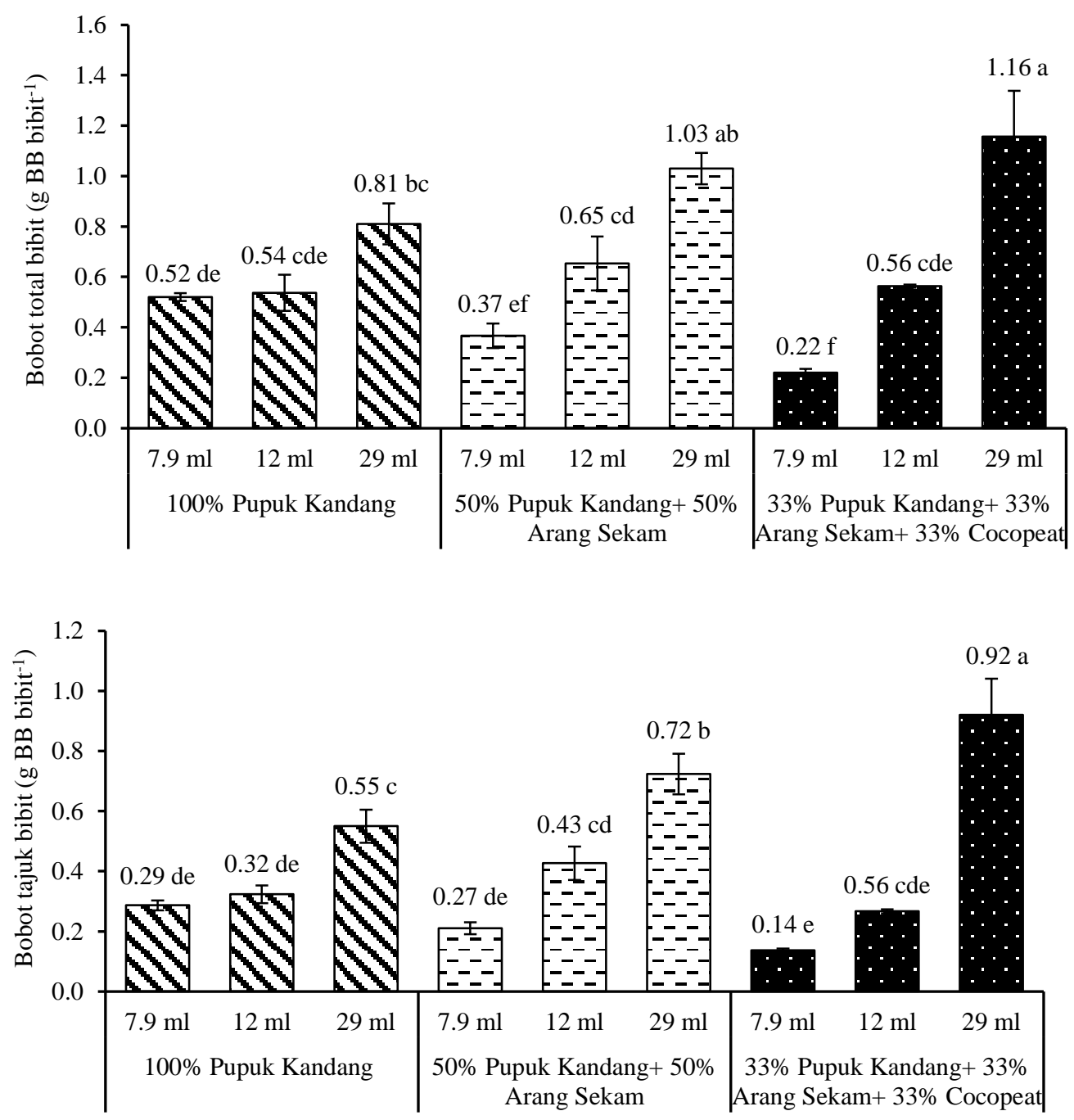

Gambar 2. Interaksi antara perlakuan jenis dan volume media tanam terhadap bobot total dan bobot tajuk bibit tempuyung (keterangan: huruf yang sama diikuti peubah yang sama menunjukkan tidak berbeda nyata berdasarkan uji DMRT \%, bar menunjukkan nilai \pm standart error). 
Tabel 2. Pengaruh perlakuan jenis dan volume media tanam terhadap bobot dan volume akar

\begin{tabular}{lcc}
\hline \multicolumn{1}{c}{ Perlakuan } & $\begin{array}{c}\text { Bobot } \\
\text { Akar }(\mathrm{g})\end{array}$ & $\begin{array}{c}\text { Volume } \\
\text { Akar }(\mathrm{mL})\end{array}$ \\
\hline Volume Media & & \\
$7.9 \mathrm{~mL}$ & $0.14 \mathrm{~b}$ & $0.17 \mathrm{~b}$ \\
$12 \mathrm{~mL}$ & $0.23 \mathrm{a}$ & $0.28 \mathrm{a}$ \\
$29 \mathrm{~mL}$ & $0.25 \mathrm{a}$ & $0.34 \mathrm{a}$ \\
\hline Media & & \\
$100 \%$ pupuk kandang kambing & 0.22 & 0.28 \\
$50 \%$ pupuk kandang kambing $+50 \%$ arang sekam & 0.22 & 0.28 \\
$33 \%$ pupuk kandang kambing $+33 \%$ arang sekam $+33 \%$ cocopeat & 0.19 & 0.23 \\
\hline
\end{tabular}

Keterangan: Angka pada tiap kolom yang diikuti huruf yang sama tidak berbeda nyata berdasarkan uji DMRT 5\%.

Terdapat pengaruh interaksi perlakuan yang diberikan terhadap panjang akar bibit tempuyung (Gambar 3). Komposisi media yang diberikan menunjukkan pengaruh yang berbeda-beda jika dikombinasikan dengan peningkatan volume media. Media $100 \%$ pupuk kandang kambing akan menghasilkan akar terpanjang jika dikombinasikan dengan volume media, padahal jika dilihat dari tajuk bobot (Gambar 2) maupun bobot akar (Tabel 2) perlakuan $100 \%$ pupuk kandang kambing memiliki nilai peubah yang lebih rendah dibandingkan dengan perlakuan media lainnya dengan volume media yang sama $(29 \mathrm{~mL})$.

Media dengan $50 \%$ pupuk kandang kambing $+50 \%$ arang sekam jika menggunakan volume media semakin besar maka semakin panjang akar yang dihasilkan, dan untuk media dengan komposisi 33\% pupuk kandang kambing $+33 \%$ arang sekam + 33\% cocopeat menunjukkan bahwa panjang akar terbaik terdapat pada volume media 12 $\mathrm{mL}$. Pola pertumbuhan akar antara media memperlihatkan bahwa pada semua jenis media, volume media yang lebih besar dapat meningkatkan panjang akar (nyata atau tidak) namun jika dikaitkan dengan bobot, dapat dilihat bahwa dengan media pupuk kandang kambing 100\% (terutama pada volume $29 \mathrm{~mL}$ ) diarahkan pada tajuk maupun akar, sedangkan media lain pertumbuhan lebih diarahkan pada tajuk.

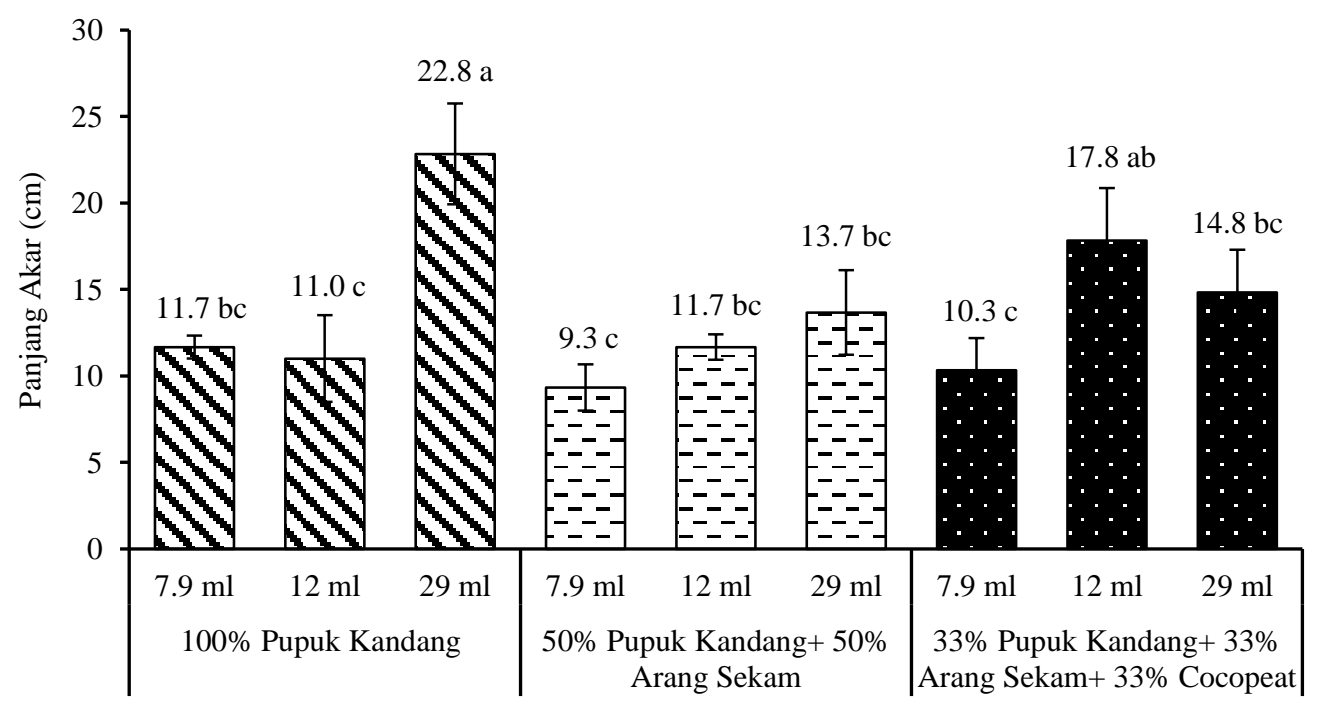

Gambar 3. Interaksi antara perlakuan jenis dan volume media tanam terhadap panjang akar bibit tempuyung (keterangan: bar menunjukkan nilai \pm standart error) 
Pengaruh Jenis dan Volume Media terhadap Peubah Kadar Bioaktif Bibit Tempuyung

Terdapat pengaruh interaksi perlakuan yang diberikan terhadap kadar total flavonoid (Gambar 4). Perlakuan komposisi media 100\% pupuk kandang kambing dan komposisi 50\% pupuk kandang kamibng $+50 \%$ arang sekan tidak memberikan hasil yang berbeda terhadap kadar total flavonoid di setiap perlakuan volume media yang di berikan, hasil penelitian Wardani dan Melati (2014) menunjukkan bahwa pemberian pupuk kandang kambing dengan berbagai dosis, tidak mempengaruhi kandungan bioaktif tanaman tempuyung.

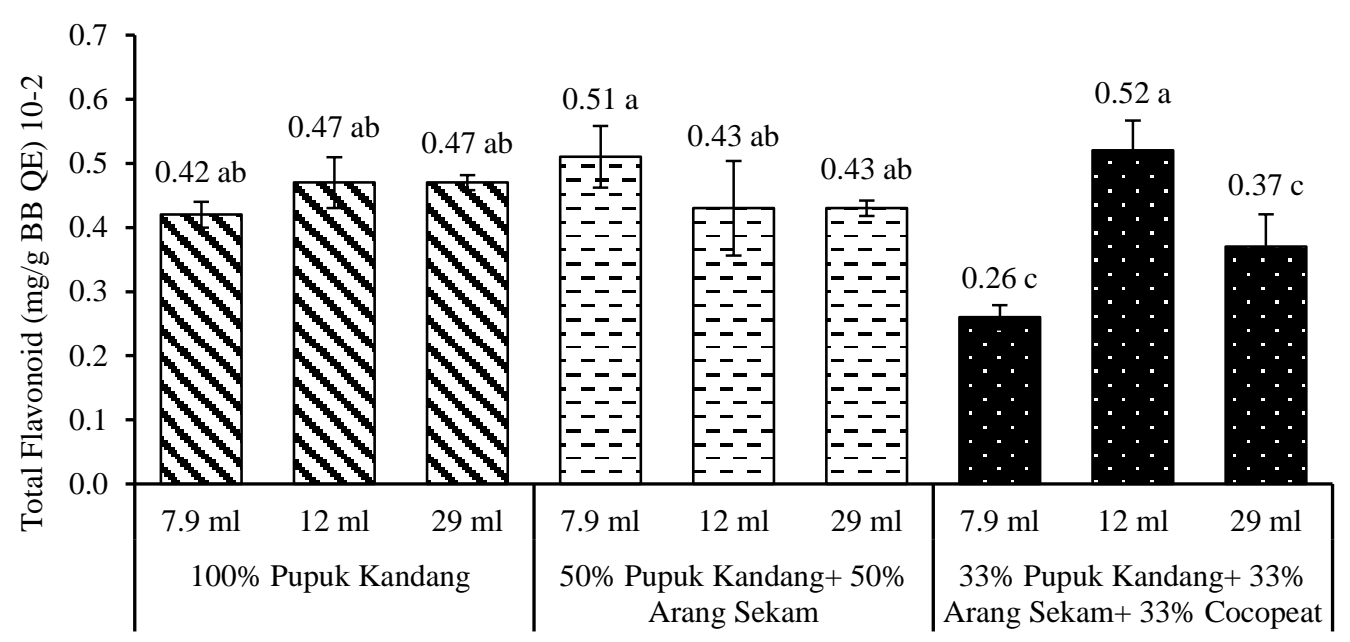

Gambar 4. Interaksi antara perlakuan volume media dan media tanam terhadap kadar total flavonoid bibit tempuyung (keterangan: bar menunjukkan nilai \pm standart error, QE: Quercetin Equivalen, BB: Berat Basah)

Perlakuan media $33 \%$ pupuk kandang kambing $+33 \%$ arang sekam $+33 \%$ cocopeat memiliki pola yang berbeda, kombinasi perlakuan media $33 \%$ pupuk kandang kambing $+33 \%$ arang sekam $+33 \%$ cocopeat dengan volume tray bertingkat, terdapat hasil yang optimum, pada volume tray $7.9 \mathrm{~mL}$ kadar flavonoid yang dihasilkan lebih kecil dari volume tray yang lainnya, sedangkan pada volume tray $12 \mathrm{~mL}$ memiliki hasil yang lebih tinggi dibandingkan dengan perlakuan volume tray yang lain, pada perlakuan volume tray 29 $\mathrm{mL}$ kadar flavonoid turun dan lebih kecil dibandingkan dengan perlakuan pada volume tray $12 \mathrm{~mL}$. Hal ini menunjukkan bahwa terdapat kondisi optimum dalam menghasilkan kadar flavonoid dengan perlakuan media 33\% pupuk kandang kambing $+33 \%$ arang sekam + $33 \%$ cocopeat.

\section{KESIMPULAN}

Terdapat pengaruh interaksi antara perlakuan volume media dan komposisi media terhadap peubah jumlah daun, panjang daun, lebar daun, bobot total dan bobot tajuk, panjang akar serta kadar total flavonoid. Dilihat dari segi efisiensi perlakuan yang bisa direkomendasikan untuk produksi masal bibit tempuyung adalah perlakuan dengan volume media $12 \mathrm{~mL}$ dengan menggunakan komposisi media 50\% pupuk kandang kambing $+50 \%$ arang sekam.

\section{DAFTAR PUSTAKA}

[Deptan] Departemen Pertanian. 2002. Rumusan Forum Koordinasi Kelembagaan Produksi Aneka Tanaman. Prosiding Forum Koordinasi Kelembagaan Produksi Aneka Tanaman, 13-16 November 2002. Jakarta.

Ghehsareh, A.M., H. Borji, M. Jafarpour. 2011. Effect of some culture substrates (date-palm peat, cocopeat and perlite) on some growing indices and nutrient elements uptake in greenhouse tomato. Afr. J. Microbiol. Res. 5(12): 14371442. 
Haryati, A., S. Kosasih. 2006. Pengaruh Medium Sapih terhadap Pertumbuhan Bibit Shorea Selenica BL. di Persemaian. Jurnal Penelitian Hutan dan Konservasi Alam. Pusat Litbang Hutan dan Konservasi Alam. Bogor.

Heni, M. 2012. Pengembangan pertanian organik di Indonesia. Forum Penelitian Agro Ekonomi. 30(2): 91-108.

Hidayati, A., Yusrin, H. Anggraini. 2009. Pengaruh frekuensi penggunaan teh daun tempuyung (Sonchus arvensis L.) terhadap daya larut kalsium oksalat $\left(\mathrm{CaC}_{2} \mathrm{O}_{4}\right)$. Jurnal Kesehatan. 2(2): 30-37.

Irawan, A., Y. Kafiar. 2015. Pemanfaatan cocopeat dan arang sekam padi sebagai media tanam bibit cempaka wasian (Elmerrilia ovalis). Pros. Sem. Nas. Masy. Biodiv. Indonesia. 1(4): 805-808.

Makkar, H.P.S., R.K. Dawra, B. Singh. 1988. Determination of both tannin and protein in a tannin-protein complex. J. Agric. Food Chem. 36: 523-525.

Mayrowani, H., T. Supriyati, Sugino. 2010. Analisa Usahatani Padi Organik di
Kabupaten Sragen. Laporan Penelitian. JIRCAS.

Pramono, S., S. Sumarno, S. Wahyono. 1993. Flavonoid daun Sonchus arvensis L. senyawa aktif pembentuk kompleks dengan batu ginjal berkalsium. Warta Tumbuhan Obat Indonesia. 2(3): 5-7.

Sabehat, A., D. Weiss, S. Lurie. 1998. Heat shock proteins and cross-tolerance in plants. Physiol Plant. 103: 437-441.

Surata, I.K. 2012. pertumbuhan semai cendana (Santalum album Linn.) pada beberapa ukuran kantung plastik di daerah semiarid. Jurnal Penelitian Kehutanan Wallacea . 1(1): 13-25.

Syukur, C., Hernani. 2002. Budidaya Tanaman Obat Komersial. 91. Penebar Swadaya. Jakarta.

Wardani, Y.E., M. Melati. 2014. Produksi simplisia dan kandungan bioaktif daun tempuyung (Sonchus arvensis L.) pada berbagai dosis pupuk kandang kambing. J. Hort. Indonesia 5(3): 148-157. 